NBER WORKING PAPER SERIES

\title{
THE ANATOMY OF EMPLOYEE INVOLVEMENT AND ITS EFFECTS ON FIRMS AND WORKERS
}

\author{
Richard B. Freeman \\ Morris M. Kleiner \\ Cheri Ostroff
}

Working Paper 8050

http://www.nber.org/papers/w8050

\section{NATIONAL BUREAU OF ECONOMIC RESEARCH \\ 1050 Massachusetts Avenue \\ Cambridge, MA 02138}

December 2000

The authors thank Hwikwon Ham, Donghoon Yang and Yongjin Nho for their assistance with this paper. This study was funded by the National Science Foundation and the Sloan Foundation. The views expressed in this paper are those of the authors and not necessarily those of the National Bureau of Economic Research.

(C) 2000 by Richard B. Freeman, Morris M. Kleiner, and Cheri Ostroff. All rights reserved. Short sections of text, not to exceed two paragraphs, may be quoted without explicit permission provided that full credit, including (C) notice, is given to the source. 
The Anatomy of Employee Involvement and Its Effects on Firms and Workers

Richard B. Freeman, Morris M. Kleiner, and Cheri Ostroff

NBER Working Paper No. 8050

December 2000

\begin{abstract}
A great many American firms have organized workplace decision-making in new ways to get employees more involved in their jobs -- using policies like self-directed work teams, total quality management, quality circles, profit-sharing, and diverse other programs. This paper uses a firm-based data set and employee-based information to illuminate several aspects about the locus and economic impacts of employee involvement (EI). Having information from employees as well as from firms allows us to ask not only what EI does for firms, the principal question in the literature on the subject, but also what EI does for workers; and to examine EI from the "bottom up" perspective of participants rather than managers. We find that EI practices are linked in an hierarchical structure that provides a natural scaling of EI activities and the intensity of the EI effort. Firms that have EI are also more likely to have profit-sharing and other forms of shared compensation. However, EI has a weak and poorly specified effect on output per worker, but it has a strong and positive impact on employee well-being.
\end{abstract}

Richard B. Freeman

NBER

1050 Mass. Ave.

Cambridge, MA 02138

and Harvard University, and LSE, Centre for Economic Performance freeman@nber.org

\section{Cheri Ostroff}

Teachers' College

Columbia University

525 W. 120th St., Box 6

New York, NY 10027

cheri.ostroff@columbia.edu
Morris M. Kleiner

University of Minnesota

Humphrey Institute and

Industrial Relations Center

260 Humphrey Center

$30119^{\text {th }}$ St. South

Minneapolis, MN 55455

and NBER

mkeiner@hhh.umn.edu 
Many American firms have organized workplace decision-making in new ways to get employees more involved in their jobs -- using human resource policies like self-directed teams, total quality management, quality circles, profit-sharing, and diverse other programs. Some firms are deeply committed to employee involvement (EI) and look upon these programs as a competitive advantage in the marketplace. Some adopt EI because they are near bankruptcy and see devolving authority to workers as a possible "way out". Others do it because they believe it is a more profitable or morally better way to operate their business. Yet other firms do it because other firms do it. In 1995 business supported the "Teamwork Act" to allow it greater leeway in establishing workplace committees (Kassebaum and Gunderson, 1995), but this act was vetoed by the President in response to trade union fears that it would open the door for companydominated unions.

How substantial are EI programs in the US, even absent legal changes easing their introduction? Is EI complementary with other personnel and labor relations practices? Do the benefits of EI accrue largely to workers or largely to firms?

This paper uses both a firm-based data set and an employee-based data set to answer these questions regarding the locus and impact of EI. ${ }^{1}$ By examining information from both firms and employees, we are able to ask what EI does for workers as well as it does for firms. Our firm based data set was developed by Cheri Ostroff through a mail Human Resource Practice (HRP) survey of high level executives in member firms of the Society for Human Resource

${ }^{1}$ See Black and Lynch, 2000, Freeman and Kleiner, 2000, Kato, 2000, Kleiner, Leonard, and Pilarski, 1999. 
Management. ${ }^{2}$ The survey was limited to 3402 firms who had more than 200 employees; 373 firms responded for an $11 \%$ response rate, which is similar to other studies that attempt to measure human resource outcomes (Kato and Morishima, 1996). The HRP data contains information on eight EI activities, on three indicators of profit-sharing, and on other human resource practices as well. We matched the data with firm-level data on production and financial outcomes from Compustat to obtain a file with data on both economic outcomes, EI activities, and profit-sharing. Our employee based data set, the 1994-95 Worker Representation and Participation Survey (WRPS), was based on a telephone survey of 2408 employees in private sector firms with 25 or more employees; and a follow-up survey of 801 respondents to the original survey ( Freeman and Rogers (1999). The survey included a module on employee involvement and questions about workplace activities and attitudes toward management and unions where EI participants might differ from other employees.

Our analysis yields three findings:

1. Employee involvement practices have been rapidly growing since the 1980 s, with the number of practices in our sample of firms increasing almost five fold over the 1983 to 1993 period. By the mid 1990s, fifty-two percent of American employees in firms with more than 25 workers reported some EI program at their workplace, thirty-one percent said that they were involved in a program.

2. EI practices are linked in an hierarchical structure that provides a natural scaling of EI activities and the intensity of the EI effort. Firms that have EI are also more likely to have profit-

\footnotetext{
${ }^{2}$ The job title of the individuals who answered the questionnaire were $41 \%$ Vice Presidents; $43 \%$ Directors; and $16 \%$ managers/specialists.
} 
sharing and other forms of shared compensation. The complementarity between sharing decision-making and sharing financial rewards lends support to agency theory models of the development of "shared capitalist" institutions (Freeman, 1999).

3. EI has a weak and poorly specified effect on output per worker, but EI has a strong and positive impact on employee well-being. EI Participants have greater say about their job; assess workplace relations more positively than other workers; have greater trust in their firm. But they also believe that management has not devolved sufficient authority to employees for EI to work most effectively. And they have less desire for unionization than other workers.

In short, the benefits to workers from employee involvement are easier to measure and potentially stronger than the benefits to firms. Perhaps just as competition in innovating in the product market largely benefits consumers rather than firms, competition in providing employee involvement in the labor market largely benefits workers rather than firms.

\section{The Extent and Locus of Employee Involvement}

To assess the extent and locus of employee involvement, we examine first the HRP Survey. This survey asked about eight EI practices, their intensity of use, and the period when they were introduced. The practices are: the extent of self-managed work teams, worker involvement of the design of EI programs, extent of TQM, committees on productivity, worker involvement in work processes, formal suggestion or complaint systems, formal information-sharing with employees, and surveys of workers regarding their satisfaction. ${ }^{3}$ The HRP also asked whether the practice was implemented 10 years earlier or more; 5-9 years earlier;

\footnotetext{
${ }^{3}$ These are not necessarily the practices we would have ideally wanted information on, but they are the most relevant practices for which the HRP survey obtained information.
} 
1-4 years earlier, or within a year; and whether the firms' use of the practice is "very great, covering $80+\%$ of jobs/workers; is "great", covering $60-79 \%$; is "moderate", covering $40-59 \%$; is "some", covering $20-39 \%$; or is little, covering $1-19 \%$ of workers. The question about the time thata firm introduced a practice allows us to conduct fixed effects before/after analyses of its impact. By posing the intensity question in terms of coverage, the survey gives a natural numeric scale from 1 to 100 that is superior to the standard yes/no dichotomy of whether a firm has a given practice.

The survey also contains three questions related to gain or profit-sharing: whether the firm links employee rewards, raises or bonuses to how well the unit or team performs (commonly called gain-sharing); whether the firm uses rewards and compensation programs that link employees' rewards to how well the company performs; and whether it provides incentives to employees to increase productivity or quality. ${ }^{4}$

Table 1 summarizes the extent of employee involvement practices in 1993 in the HRP data. The statistics on the percentages of companies with a given practice in 1983 and 1993, show a sharp rise in the proportion of firms with various employee involvement practices in this sample of firms. In 1983 there were 1.47 EI practices per firm, whereas in 1993, there were 6.16 practices per firm - a huge growth in a decade. The intensity scale figures in the table show a comparable pattern of growth in the mean proportion of workers covered by the practice in all firms and the mean proportion covered among those with the practice in 1993. The last columns of the table give the distribution of firms by the years that the firm had the practice. Virtually all

4 It also questions on other aspects of personnel practices, ranging from affirmative action programs to complaint systems and training, that we do not explore here. 
firms have mechanisms for employees to communicate suggestions or register complaints and formal procedures for sharing information. But even these practices vary among firms in their intensity of usage. Most firms "involve employees in major decisions that will directly affect their work processes" but place the intensity of involvement in the some to moderate category, with an average score of 38 -- implying that about $38 \%$ of the work force is covered by the activity. ${ }^{5}$ Nearly three in four companies regularly survey worker opinions, but the numerical intensity score for opinion surveys falls below that for involving employees in work process decisions. The least common practice and the one with the smallest intensity of use among firms is whether the firm "utilizes autonomous work groups or self-managed teams" in assigning work and determining work methods. This is arguably the most advanced EI practice.

The data on the years for which the firm has used the practices are inversely correlated to the intensity measures of the practices. The practices used most intensively -- information sharing, suggestion/complaint systems -- have longer years in use than the practices used less intensively, such as opinion surveys or giving workers a role in designing labor practices. One interpretation is that firms introduce a practice gradually and increase its use over time. This in turn suggests that the practices may fall into a reasonably well-ordered hierarchy or scaling that would reflect a latent structure that placed firms along a single thermometer style scale, greatly simplifying the multi-variate data (Bartholomew, 1996).

To see the extent to which the data follow such a pattern, Table 2 shows the interrelations among practices by firms in 1993. The upper part of the table records the proportion of firms

\footnotetext{
${ }^{5} \mathrm{We}$ treat the intensity measure as a scaled ordering, from 0 to 100 , of the company's practices. It is unlikely that managers in fact knew the percentages of workers covered.
} 
with a given practice that have the other practices. For instance, the numbers in the first column tell us that of the firms with the least prevalent EI activity -- involving self-managed work teams -- $45 \%$ also have EI in the design of HR practices; $59 \%$ also involve workers in decisions on human resource processes; $58 \%$ have suggestion systems; and 59\% also have information sharing. The lower part of the table divides the intensity of usage into two groupings: high intensity (those with 60+ percent usage of the practice); and those with lower intensity of use. The numbers in this part of the table show the proportion of firms with a high intensity in each of the variables. For instance, the figures in the column for self-managed teams says that of the firms with a high intensity giving workers autonomy $3.7 \%$ also had a high intensity of using opinion surveys, $7.8 \%$ of sharing information with employees.

If there was a single dimensional ordering for the eight EI practices, no firm would have a more advanced practice without also having a less advanced practice. This would give table 2 a triangular shape, with $100 \%$ figures above the diagonal and smaller numbers below the diagonal that wiykd drop from the more to the less advanced practices, per Guttman scaling. The table fits this pattern imperfectly. The columns to the far right of the table show the distribution of firms by the number of other practices that they have. If the matrix were perfectly triangular, these numbers would also have a distinct pattern. Firms having the rarest practice would have all 7 others; and firms with more common practices would have fewer additional practices. For instance, firms with the second most common practice would have the most common practice but would not have the rarer more advanced practices. Again, this is roughly what we find. For example, 12.1 percent of firms with high intensity self-managed teams have great intensity for all 
the other practices, but only 1.7 percent firms with high information-sharing have this intensity level for all the other policies.

The seeming ordering of EI practices suggests that we could rank firms by their EI activity: those with high levels of intensity for the most advanced feature would have the highest ranks; those with lower levels of intensity for that feature would be next; followed by those with high intensity for the second most advanced features and so on. One latent variable model that fits these data well are Rasch-type models (Wong, 1997). ${ }^{6}$ Rasch models use a logit form to estimate the latent ability (EI progressiveness) of respondents (firms) who answer a set of questions (EI practices) of varying difficulty or advancement. The latent ability or progressiveness measure is the thermometer scale. An even simpler way to summarize the data in Table 2 is to form a summated rating by adding together the levels attached to different responses (Barthalomew, 1996). With a 0/1 coding for the presence or absence of a practice, a firm with six practices gets a 6 scale, while one with 3 practices gets a 3 scale, and so on. We formed both Rasch and summated ratings for the EI questions on the HRMS survey. Figure 1 shows the distribution of firms by the Rasch and summated ratings measures of EI.. The two summary statistics give similar scalings, with a correlation coefficient of .74 across the firms. Because the summated ratings are easier to calculate and more transparent, we use them in our empirical analysis, but our results hold for Rasch scalings, and indeed, for factor analytic methods of forming a single factor model as well.

\section{Complementarity Between EI and Financial Sharing?}

\footnotetext{
${ }^{6}$ Rasch type models have the following properties. They are unidimensional, require discrete observations, require statistical independence, and can be estimated using maximum likelihood techniques (Andrich, 1988). If the latent variables are continuous then the standard technique is factor analysis.
} 
Agency theory predicts that shared decision-making through employee involvement schemes should be complementary with shared compensation practices. The reason is simple: when management devolve decisions to employees, it will want to incentive those workers to make decisions that raise the value of the firm; and conversely, when management pays workers on the basis of the performance of the firm, it will want to give them the authority to make decisions that raise that performance.

Table 3 uses the HRM data file to examine this prediction. We calculate the proportion of workers covered by profit-sharing, gain-sharing, or by programs that provides incentives to employees to increase productivity or quality for companies with different intensities of employee involvement activity. For simplicity, we divided the companies by quartiles, with the top quartile consisting of companies having the most intense EI programs and the other quartiles having correspondingly less activity. If the complementarity hypothesis is correct companies in the upper parts of the EI distribution will have high proportions of workers with incentive pay. For profit-sharing and incentives to improve productivity or quality, there is a strong monotonic relation, with the proportion covered falling as EI intensity falls. For gain-sharing the relation is weaker. Companies in the top quartile of EI intensity have $39.6 \%$ of workers covered by gainsharing while those in the bottom quartile have $22.2 \%$, but the drop is not monotonic. Averaging the percentages covered by the three forms of incentive pay, we get the results in the final column, where the percentages drop noticeably as EI intensity falls. The correlation coefficient between the intensity of EI and the proportion with profit-sharing is 0.29 ; the correlation between the intensity of EI and the proportion with gain-sharing is 0.25 ; the correlation with incentives is 0.41 ; and the correlation with the composite measure of all three forms of incentive pay is .44 . 


\section{EI Effects on Firm Outcomes}

To see whether employee involvement activities affect productivity, we matched the HRP file with data on sales, employment, and capital from Compustat -- a matching that reduced our sample size to 260 firms $^{7}$. We then estimated log-linear production functions with measures of EI as independent variables. Our output measure is sales; employment is number or employees in the company, capital is total assets. Appendix A.1 shows that the industry mix in our sample roughly matches that in Compustat. We estimated log-linear production functions with measures of EI as independent variables. Our output measure is sales; employment is number or employees in the company, capital is total assets. Appendix A.2 gives the means and standard deviations for the production function variables of firms in 1983, which is before most firms introduced advanced EI practices, and in 1993.

Our analysis is based on a fixed effects production function analysis that exploits the fact that we have longitudinal data on the intensity and timing of EI practices. Because the survey asked or a range of years when the program was implemented, however, we cannot identify the precise years when the firm has a program and when it does not. Our solution is to approximate the existence of a program in a given year by assuming that the program had a uniform probability of being introduced in one of the years in the reported range. For a program introduced three to five years ago, this leads to a one-third chance that the program existed five years ago, a two-thirds chance that it existed four years ago, and certainty that it existed three

\footnotetext{
${ }^{7}$ Comparing firms in the matched HRP-Compustat data set with firms in the total Compustat file, we found that the firms in the matched file had more employees (15,004 on average versus 9,351 for other Compustat firms), and correspondingly larger net sales and income; but were similar to other firms in capital/labor ratios, output per employee, market-book value, and return on equity.
} 
years ago. Because the survey asked for intensity of use only in 1993, we estimated the intensity of use in earlier years by exploiting the fact that intensity of use is highly correlated with the length of time a program has been in place. We regressed the intensity of use on the length of program life for all companies and programs taken together in 1993, and used the estimated coefficients to predict the unobserved intensity in the years prior to 1993.

Given the estimated probability that a firm had a particular EI or group financial incentive plan in a given year (p') and the estimated intensity of use (U') in that year we calculated a scale of EI and Profit-sharing activity for each year and program as the product p'U' and then summed the values across programs by firm in each year. This yields measures of both the number of programs and their intensity of use in every firm in a given year. With these data, we estimate the effect of EI using the following production function 1) $\ln Q=a+b(\ln K)+c(\ln L)+d(E I)+e(P G I)+Y R+F I R M+u$ where $\mathrm{Q}=$ sales, $\mathrm{L}=$ employment, and $\mathrm{K}=$ book value of assets from COMPUSTAT, FIRM is a vector of year dummy variables, EI is our employee involvement scale, PGI is our measure of the extent of profit-sharing, gain-sharing and incentive pay, and $u$ is the residual. With firm and year dummy variables, identification of an EI effect comes from the differential variation of EI over time within firms.

Given our sample size, and the standard deviations of outcomes among companies, what might we expect from the analysis? For simplicity consider the sample size we would need to detect a difference between EI and non-EI firms (or between the same firm before/after introduction of EI) if EI in fact raised productivity by 0.05 , or $5 \%$. If the standard deviation of productivity among firms was 0.50 - a reasonably moderate value given the wide distribution of 
productivity - the critical size effect for detecting the .05 effect of 0.10 . To detect such an effect at the five percent significance level with an $80 \%$ chance of success we would need roughly 600 observations (Kraemer and Thiemann, p. 105). With a sample of approximately 270, as in our case, the power statistic is just 50\%, implying that if EI truly had a 0.05 effect, we would have only a fifty-fifty chance of detecting it at a 5\% significance level. Thus, unless EI has much larger effects than we expect, we are at best likely to find only modest significant regression coefficients with our sample. ${ }^{8}$

\section{Results}

Table 4 summarizes our production function regressions using ordinary least squares (OLS) and median regressions under three different specifications. First, we analyze annual data, with year and dummy variables included. The OLS results here show no impact for EI on productivity and a positive but insignificant effect for our group incentive variable. The median regressions give a comparable negligible result for EI but give a positive and significant impact to the group incentive variable. These results suggest that the estimates are sensitive to the mode of the regression approach. Second, we estimated a production function for the last year in our sample, 1993. Regressions based on annual data suffer from the potential problem that there may be costs of adjustment to introducing EI and group incentive pay policies that delay its benefits to the firm. By 1993, many of the programs should have been relatively mature and thus might be expected to have larger effects on productivity. The estimated coefficients on EI in these

\footnotetext{
${ }^{8}$ The statistic is more complicated than this for a multiple regression analysis. The critical size effect in this case depends also on the variance of the EI measure and its correlation with other independent variables. The smaller the variance of the EI measure and the greater its correlation with other explanatory variables, the larger is the sample size needed for the power. But this reinforces our point, that we should not expect strongly significant results with our sample size. (See Kraemer and Thiemann, p. 65).
} 
calculations in lines 3 and 4 are negligible, but the incentive pay variable has a significant positive effect in the OLS cross-section model. Third, we took a long period change perspective and estimated the production function using changes over the 1983-93 decade; here, we transformed the data into average annual changes so that we could include firms for which we did not have data going back to 1983. The results, given in lines 5 and 6 again show no EI impacts on productivity, but do reveal a modest effect of incentive pray programs.

Overall, our analysis cannot detect an EI effect on productivity. We find some evidence that incentive pay affects productivity, albeit one that varies with estimating technique and specification. Perhaps a data set with a larger set of observations may show effects of EI policies that our data set fails to reveal, but work by Capppelli and Neumark (1999) and by Black and Lynch (2000) support our findings in a larger US data set, while work by Conyon and Freeman (2000) also find little productivity effect for EI type programs in UK data.

\section{Benefits to Employees from EI}

Do employees in an EI program benefit from EI? Do they perceive improvements in productivity or product quality as a result of EI? Does their work life improve?

To answer these questions, we turn to the WRPS. The WRPS includes workers in many smaller firms (the cut-off for the survey was 25 workers), ${ }^{9}$ so it provides us with a better measure of the extent of EI in the economy than the HRP or other employer-based data sets. It also provides us with information on the characteristics of workers in EI programs that firm-based data sets do not contain. Appendix B records the percentage of workers in the WRPS who

\footnotetext{
${ }^{9}$ There was no noticeable difference in the demographic characteristics of respondents and non-respondents in the WRPS. The percentages given in this paper use national sampling weights, but because the proportions of various groups were roughly at national figures, the proportions that use the "raw" figures are comparable.
} 
participate in an EI program; the percentage of workers in firms with EI programs who do not participate in EI programs; and the percentage of workers in firms without EI. In 1994-95 roughly half of the workforce in the U.S. was in a firm with an EI program and nearly one-third of workers participated in a program. In general, more advantaged workers in larger firms are more likely to have EI than other workers in larger firms or workers in smaller firms. EI is more common among manufacturing workers than among workers in other sectors, though even in retail trade $20 \%$ of workers are EI participants and another $17 \%$ report that their firm has an EI program, though they do not participate in it. Union workers are more likely to be involved in EI programs than nonunion workers. Appendix B also shows that employee involvement is more prevalent among more skilled workers compared to less skilled workers; among white collar workers compared to blue collar workers; among workers in "prime working years" compared to younger or older workers; and among college graduates compared to less educated workers.. While the proportion of men and women reporting EI programs at their firm is similar (52\% of men versus $51 \%$ of women) men are more likely to participate. This may reflect the lack of EI programs for many clerical staff.

To determine how EI affects workers, we employed a two-part methodology. First, we examined what participants say about the effect of EI on their work life. :Presumably, workers responded to the question by comparing their workplace with EI to their workplace absent EI, but could also be comparing their situation to that of non-participants in their firm or to workers in companies without EI. The survey was imprecise in specifying the appropriate counterfactual. Second, we compared what participants in EI programs report about their work life with what non-participants in companies with EI report and with what persons in companies without EI 
programs report. Here, the comparison groups are clear, and because firms with EI may have other desirable human resource practices, the difference between participants and nonparticipants in those companies provides a particularly sharp contrast. Any difference between them must be due to actual involvement with EI rather than being in a "good" company.

\section{How EI Participants Assess Programs}

Table 5 summarizes the responses of participants in EI programs about their experiences. The principal benefit workers report is that they get "more influence on their job", though $36 \%$ also reported that they received an increase in pay from the EI program. One quarter reported that as part of the program, they talked about wages and benefits (which is illegal under Section 8(2)(a) of the NLRA). While most paticipants see themselves as benefitting, they give a mixed report on the effectiveness of the programs in improving productivity or quality. A third say that the programs have been very effective in doing so, while just $11 \%$ view the programs as not effective, whereas the majority regard the programs as only "somewhat effective". Non-EI participant workers in firms with EI programs have, moreover, a much less favorable assessment of the effects of their company's program; $21 \%$ of these workers regarded the program as not too or not at all effective compared to just $14 \%$ who regarded it as very effective. One possible explanation is that EI programs in firms with many non-participants are not very "advanced". Another is that persons who are not part of an EI activity in a company with EI feel left out even when the program is effective (for other workers). That over four-fifths of EI participants said that they believed that their firms' program would be more effective if employees had a greater say in how the program was run, provides some support for the advanced/not advanced interpretation. 
Finally, to summarize overall employee attitudes toward EI, the WRPS asked workers how they would feel if the firm abolished their program. Here, the counterfactual is clear: work life with EI and work life without it in the same firm. It is also a very real possibility, given that mergers and acquisitions, as well as changes in managerial style and beliefs depending on CEOs and other top officials, could easily lead to a change in the way the firm operates. The vast majority of EI participants said that getting rid of their firms' employee involvement program would have bad or very bad effects on them personally.

Table 6 examines how EI programs affect the way workers perform their jobs by comparing how EI participants, non-participants in firms with EI, and workers in other firms respond to the same question about their workplace. If EI is effective in giving workers more influence on the job, participants in programs should report that they have greater say in what goes on in their jobs than do other workers. Accordingly, the first panel gives the responses to questions that asked workers to rate their involvement in different decisions on the job. The answers ranged from "a lot" to "some" to "only a little" to "none". For ease of presentation, we summarize the responses in terms of the proportion reporting a lot and the proportions reporting only a little or none, with the "some" group missing. Since the WRPS module on workers having influence on their job preceded the module on EI, there is no danger that responses to the EI question colored responses to the questions about influence on the job. Issue by issue, EI participants reported that they have a greater say in workplace decisions than other workers. In some areas the differences are striking. More EI workers than other workers have a lot of direct involvement in setting goals for their work group, deciding what training is needed, or how to work with new equipment or software. Far more EI participants claim that they have a lot of 
involvement in their own work schedules or that of their work group than do other workers. ${ }^{10}$ In addition, many more EI participants report themselves as supervising other workers than do nonEI participants, consistent with the notion that the firm has in fact devolved some such functions to them.

Given their greater involvement in decisions about their work, EI participants should be particularly satisfied with their say in their firm. In fact, over one third reported themselves as very satisfied with the "influence (they) have in company decisions that affect (their) job or work life" compared to $19 \%$ of other workers. Greater satisfaction with influence in turn makes EI participants more likely to look forward to going to work and less likely to wish they didn't have to go than other workers. ${ }^{11}$

While these cross-section differences do not prove that introduction of an EI program changes employee attitudes (only a genuine longitudinal experiment could do that), the fact that participants in EI programs report greater influence and satisfaction with their influence than non-participants in companies with EI programs, supports the notion that there is something more than a "good company" effect in the pattern. We did not anticipate that the responses of non-EI participants in firms with EI would correspond more closely to those of persons in firms with no EI program than to those of EI participants. The most plausible interpretation of these contrasts is that in fact EI programs considerably improve work lives.

\footnotetext{
${ }^{10}$ Multiple regression analyses show that these differences are not due largely to the differences in the composition of the workers or of the firms shown in Table 7.

${ }^{11} \mathrm{We}$ expect this difference to translate into lower turnover and fewer absences for EI participants than for other workers, but have no evidence on this point.
} 


\section{Attitudes Toward the Firm and Employee Organizations}

If employee involvement programs are associated with positive outcomes for employees and if most EI participants say that their firms' program improves their working life, we would expect that EI participants would have a more positive view than other workers toward the firm and its management and its labor practices. They also should be less interested in unionization or other employee organizations than other workers.

The tabulations in Table 7 confirm these expectations. The first panel shows that participants in EI programs are more loyal to their employers than other workers and have greater trust that their company will keep its promises to them. It also shows that EI participants view labor-management relations as better than do other workers. Here, the WRPS used a split question design. It asked half of the sample to rate employee and management relations on a scale ranging from bad to excellent. More EI participants gave their firm "excellent" than other employees. It asked the other half of the sampl to compare their employee-management relations with that in other firms. While most workers rate their firm as better than average, EI participants are more likely to report that relations between employees and management were better than average than other employees. Finally, asked to use a school grade metric, three times as many EI participants give their firm an A in concern for employees than give their firm a D or F grade. By contrast, other employees are evenly split between those who give their company an A and those who give it a $\mathrm{D} / \mathrm{F}$ grade in its concern for employees.

The second panel in Table 7 summarizes employee views about the effectiveness of company labor relations practices. The first question asks them to evaluate the overall effect of the company's system for resolving workplace problems. The next two ask about the 
effectiveness of two widespread policies from respondents who reported having such practices at their firm. The results are clear: participants in EI programs have a more favorable view of the operation of these policies than do other workers. ${ }^{12}$ The more favorable view of the effectiveness of the company's labor relations practices among EI participants translates, moreover, into a greater willingness of employees to deal with workplace problems individually rather than collectively. Here, the WRPS asked another split question: half of respondents were asked whether they would feel "more comfortable raising workplace problems through an employee association, rather than as an individual" and half were asked whether they "would feel more comfortable dealing directly with management yourself, or . . . having a group of your fellow employees (to) help deal with management". By putting the group response second and stressing direct dealing, the second question should "tilt" answers toward the individual response. As the table shows, this is the case, with the majority of employees favoring an association in the first question but favoring individual action in the second. But, in both EI participants are more favorably inclined to individual action.

The last panel of Table 7 examines employee attitudes toward workplace organizations, including trade unions. Most employees in companies without unions or employee committees that regularly meet with management believe that if employees chose their own representatives to discuss problems with management, this would be a more effective way of dealing with problems than their current system. But EI participants are less likely to desire such a program.

\footnotetext{
${ }^{12}$ Their favorable view may reflect the programs effectiveness because EI companies are "good employers", though this would not readily explain the difference in responses between EI participants and non-participants in companies with EI; the programs work more effectively in tandem with EI; or that EI participants have a more positive perception about company programs that work no better than those in other firms.
} 
On average about one in three nonunion private sector workers in the U.S. say that they would vote for a union in a representation election. The proportion favorable to unions differs noticeably by whether or not a firm has an EI program. EI participants and workers in firms with EI programs are less likely to say they would vote union than other workers and report that their fellow employees are less likely to vote union. Similarly, EI participants took a more promanagement view regardingt the best way to operate an employee organization within the firm. ". EI participants were more favorably inclined than non-participants to allow management to resolve a disagreement between an employee organization and management, rather than to rely on an arbitrator, and wanted the company to fund the employee organization rather than having it be "truly independent. Finally, while EI participants, like other employees, feel that current labor laws give too little protection to workers for being fired without cause, they are less inclined to this view than others.

The fact that EI is more prevalent among union workers raises another issue: how does having an EI program affect the attitudes of workers towards their union. The last line in Table 7 shows that union members who participate in EI are two to two and a half times as likely to report their experience with the union as positive as non-participants. To the extent that an EI program succeeds, it seemingly improves employee attitudes toward the union as well as toward the firm.

In sum, participants in EI programs have more favorable attitudes toward their company, its labor policies, and management than others, and are also more favorable toward their union if they are unionised. But, EI participants are less likely to want union or other collective modes of solving problems. 


\section{Conclusion}

Our analysis could not identify the effects of EI on firm outcomes, but found that EI was associated with substantial improvements in the work lives of employees. Since our crosstabulations of the WRPS information on workers fails to control for either fixed firm or individual effects, it is possible that the strong results for workers are due to the selectivity of

firms or of employees into EI programs. Perhaps good firms treat workers well and introduce EI, and workers attribute the good treatment to EI. Absent some random design or natural experiment for introducing EI, we cannot prove causality on the worker side. Still, the large differences between EI and non-EI participants suggests that EI could do more for workers than for firms. At the minimum, our analysis finds that it is much easier to identify the benefits to workers than it is to assess the effects of EI on productivity and thus on the firm. 


\section{References}

Andrich, David, Rasch Models for Measurement, Sage Publications, 1988.

Aoki, Masa. "Horizontal vs. Vertical Information Structure of the Firm," American Economic

Review, Vol. 76, no. 5, December, 1986, pp. 971-983.

Athey, Susan, and Scott Stern. "Empirical Framework for Testing Theories About Complementarity in Organizational Design,” Working Paper MIT, p. 47, 1996.

Black, Sandra E. and Lynch, Lisa. "How to Compete: The Impact of Workplace Practices and Information Technology on Productvity,” National Bureau of Economic Research, Cambridge, MA. Working Paper No. 6120, August 1997. . "What's Driving the New Economy: The Benefits of Workplace Innovation," National

Bureau of Economic Research, Cambridge, MA. Working Paper No.7479, January 2000.

Bartholomew, David. The Statistical Approach to Social Measurement, Academic Press, London, 1996.

Bound, John, D. A. Jaeger, and R. M. Baker. "Problems with Instrumental Variables Estimation When the Correlation Between the Instruments and the Endogenous Variable is Weak," Journal of the American Statistical Association 90, 1995, pp. 443-450.

Cappelli, Peter and Neumark, David. “Do High Performance Work Practices Improve Establishment-Level Outcomes?" National Bureau of Economic Research, Cambridge, MA., Working Paper No. 7374, October 1999.

Conyon, Martin J. and Richard B. Freeman, "Shared Modes of Compensation and Firm Performance: UK Evidence". Presented at the NBER-LSE-IFS Conference Seeking a Premier League Economy, December 8, 2000, LSE, London.

Freeman, Richard “The Road to Shared Capitalism” Robbins Lectures, London School of Economics, 1999 
Freeman, Richard, and Joel Rodgers. What Do Workers Want?, Cornell University Press, Ithaca, New York, 1999.

Freeman, Richard, and Morris Kleiner, "Who Benefits Most from Employee Involvement: Firms or Workers?, American Economic Review, May 2000, Vol. 90, No. 2. pp. 219- 223.

Ichniowski, Casey, Kathryn Shaw, and Giovanna Prennushi. "The Effects of Human Resource Management Practices on Productivity: A Study of Steel Finishing Lines,” American Economic Review, June 1997, pp. 291-313.

Kato, Takao, “The Recent Transformation of Participatory Employment Practices in Japan”, Working Paper 7965, National Bureau of Economic Research, Cambridge, MA. , and Motohiro Morishima. "The Productivity Effects of Human Resource Management Practices: Evidence From New Japanese Panel Data," Working Paper presented at the NBER Conference on "What Do Employers Do? The Roles of Firms in Internal and External Labor Markets," December, 1996.

Kassebaum, Nancy and Steven Gunderson, "Teamwork for Employees and Management Act of 1995,” H.R. 743, 1995.

Kleiner, Morris, Jonathan Leonard, and Adam Pilarski, “Do Industrial Relatgions Affect Plant Performance? The Case of Commercial Aircraft Manufacturing, National Bureau of Economic Research, Cambridge, Ma. Working Paper 7414, November 1999.

Kraemer, Helena Chmura, and Sue Thiemann. How Many Subjects? Newbury Park, CA: Sage Publications, 1987.

Petree, Daniel, L. "Impact of Areawide Labor-Management Committees on Local Labor Climate, Firm Location and Employment," Ph.D. Thesis, University of Kansas, 1993.

Wang, Andrew. "Economic Reform and State Enterprise Productivity in China: An Application of Robust Estimation and Latent Variable Measurement Methods," Ph.D. Thesis, Harvard University, 1997. 
Table 1. The Distribution of Five Employee Involvement Activities, 1993.

\begin{tabular}{|c|c|c|c|c|c|c|c|}
\hline & \multicolumn{2}{|c|}{$\begin{array}{c}\% \text { of } \\
\text { Companies }\end{array}$} & \multirow{2}{*}{$\begin{array}{c}\begin{array}{c}\text { Mean } \\
\text { Intensity Scale }\end{array} \\
\text { All Co's } \\
\end{array}$} & \multicolumn{4}{|c|}{ Years in Use } \\
\hline & 1983 & 1993 & & $<1$ & $1-5$ & $6-9$ & $>10$ \\
\hline $\begin{array}{l}\text { Have procedures for sharing important information } \\
\text { with employees }\end{array}$ & $37 \%$ & $92 \%$ & 62 & 0.1 & 0.3 & 0.2 & 0.4 \\
\hline $\begin{array}{l}\text { Have mechanisms in place for employee } \\
\text { suggestions/complaints }\end{array}$ & $33 \%$ & $92 \%$ & 60 & 0.1 & 0.3 & 0.2 & 0.3 \\
\hline $\begin{array}{l}\text { Involve employees in major decisions that directly } \\
\text { affect their work processes }\end{array}$ & $18 \%$ & $87 \%$ & 37 & 0.1 & 0.3 & 0.2 & 0.2 \\
\hline $\begin{array}{l}\text { Establish committees/teams of employees who } \\
\text { examine productivity and quality problems and } \\
\text { provide recommendations for changes }\end{array}$ & $11 \%$ & $73 \%$ & 36 & 0.1 & 0.3 & 0.1 & 0.1 \\
\hline $\begin{array}{l}\text { Regularly survey the opinions of workers regarding } \\
\text { their job conditions and satisfaction }\end{array}$ & $20 \%$ & $74 \%$ & 38 & 0.1 & 0.2 & 0.1 & 0.2 \\
\hline $\begin{array}{l}\text { Use a total quality management approach to } \\
\text { improve productivity and service }\end{array}$ & $8 \%$ & $70 \%$ & 38 & 0.1 & 0.3 & 0.1 & 0.1 \\
\hline $\begin{array}{l}\text { Involve employees in design and administration of } \\
\text { compensation systems, performance evaluation } \\
\text { systems, methods for enhancing productivity }\end{array}$ & $13 \%$ & $68 \%$ & 22 & 0.2 & 0.3 & 0.1 & 0.1 \\
\hline $\begin{array}{l}\text { Utilize autonomous work groups or self-managed } \\
\text { teams who have responsibility for decisions, } \\
\text { assigning work, and determining work methods }\end{array}$ & $5 \%$ & $61 \%$ & 20 & 0.2 & 0.3 & 0.1 & 0.1 \\
\hline
\end{tabular}

Source: Tabulated from HRP data file, with N=260

Numbers in parenthesis are the standard deviations for the intensity measures.

The mean intensity scale was calculated by taking the average $\%$ of workers covered by the activity as indicated by the qualitative/quantitative response categories:

very great $--80 \%$ or more of jobs/employees covered by activity

great -- $60-79 \%$ of jobs/employees covered by activity

moderate -- $40-59 \%$ of jobs/employees covered by activity

some $-20-39 \%$ of jobs/employees covered by activity

little -- $1-19 \%$ of jobs/employees covered by activity

The years in use data group in the $<1$ category two responses, in use for less than a year and plan to use/implement within the year. 
Table 2. The Percentage of Firms with Varying Combinations of Employee Involvement Policies.

\section{A. HaVing PRACTICES (PERCENT)}

With Number of Other Practices (\%)

\begin{tabular}{|c|c|c|c|c|c|c|c|c|c|c|c|c|c|c|c|}
\hline & \multirow{3}{*}{$\begin{array}{l}\text { Self-Managed } \\
\text { Teams }\end{array}$} & \multirow[b]{2}{*}{ Design } & \multirow[b]{3}{*}{$T Q M$} & \multirow{3}{*}{$\begin{array}{l}\text { Opinion } \\
\text { Surveys }\end{array}$} & \multirow{3}{*}{$\begin{array}{l}\text { Committees on } \\
\text { Productivity }\end{array}$} & \multirow{3}{*}{$\begin{array}{l}\text { Involvement } \\
\text { in Work } \\
\text { Processs }\end{array}$} & \multirow[b]{2}{*}{ Suggestions/ } & \multirow[b]{3}{*}{0} & \multirow[b]{3}{*}{1} & \multirow[b]{3}{*}{2} & \multirow[b]{3}{*}{3} & \multirow[b]{3}{*}{4} & \multirow[b]{3}{*}{5} & \multirow[b]{3}{*}{6} & \multirow[b]{3}{*}{7} \\
\hline & & & & & & & & & & & & & & & \\
\hline & & Labor & & & & & Complaints & & & & & & & & \\
\hline Self-Managed & -- & & & & & & & 0 & 0.9 & 0 & 4.4 & 7 & 10.1 & 21.9 & 55.7 \\
\hline \multicolumn{16}{|l|}{ Teams } \\
\hline Design Labor & 45 & & & & & & & 0 & 0.8 & 2 & 3.3 & 8.2 & 13.9 & 19.7 & 52 \\
\hline TQM & 52 & 50 & & & & & & 0.4 & 0.4 & 0.8 & 2.7 & 7.5 & 15.3 & 23.1 & 49.8 \\
\hline Opinion Surveys & 49 & 55 & 56 & & & & & 0 & 0.7 & 2.6 & 4.1 & 8.2 & 14.6 & 22.4 & 47.4 \\
\hline Committees on & 53 & 54 & 59 & 57 & & & & 0 & 0.7 & 2.2 & 3.3 & 7.4 & 16.2 & 23.2 & 46.9 \\
\hline \multicolumn{16}{|l|}{ Productivity } \\
\hline Involvement in & 59 & 62 & 64 & 68 & 68 & & & 0 & 1.5 & 3.1 & 5.5 & 12 & 17.8 & 20.9 & 39.1 \\
\hline \multicolumn{16}{|l|}{ Work Process } \\
\hline Suggestions/ & 58 & 62 & 65 & 69 & 69 & 84 & & 1.2 & 2.3 & 5.8 & 7.8 & 11.3 & 15.9 & 19.1 & 36.7 \\
\hline \multicolumn{16}{|l|}{ Complaints } \\
\hline Information & 59 & 64 & 66 & 69 & 70 & 83 & 87 & 0.9 & 2.3 & 4.6 & 7.5 & 11.6 & 16.2 & 20 & 36.8 \\
\hline Sharing & & & & & & & & & & & & & & & \\
\hline
\end{tabular}


Table 2 continued ...

B. Making Intense Use of Practices (PERCENT)*

With Number of Other Practices (\%)

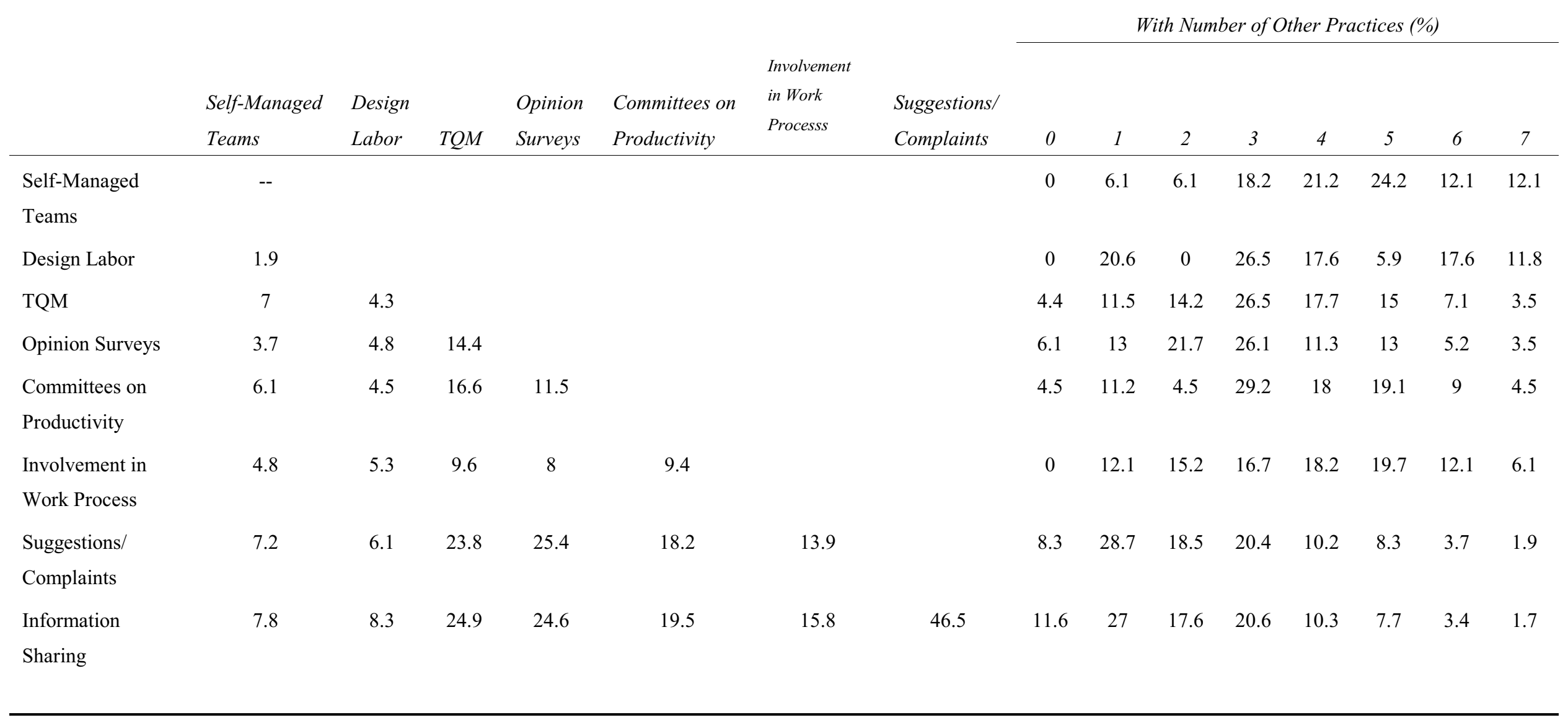

Sourre: Calculated from HRP data file.

*Making intense use means that 60 percent or more of the employees are covered and the use is great or very great. 
Table 3 : Percentage of Workers Covered by Incentive- Based Compensation, by Extent of Employee Involvement*

\begin{tabular}{|c|c|c|c|c|}
\hline $\begin{array}{l}\text { Companies, } \\
\text { By Quartile in Extent } \\
\text { of } \mathrm{EI}^{\mathrm{a}}\end{array}$ & Gain-sharing & Profit-sharing & Incentive & Average \\
\hline Top 25 percent** & 44.2 & 66.7 & 53.8 & 54.9 \\
\hline second 25 percent & 31.1 & 53.2 & 40.5 & 41.6 \\
\hline third 25 percent & 36.9 & 47.9 & 37.6 & 40.8 \\
\hline lowest 25 percent & 25.6 & 44.1 & 18.9 & 29.5 \\
\hline
\end{tabular}

${ }^{\text {a }}$ Companies ranked by intensity of EI coverage, calculated as the sum of the percentages covered by the eight programs

* These values include the intensity of EI coverage by the number of firms and intensity of the incentive-based coverage in each category.

**This grouping contains 69 firms because of ties in the EI index values.

Percentages with the program calculated on the basis of responses as follows:

very great -- $80 \%$ or more of jobs/employees covered by activity $-90 \%$

great -- $60-79 \%$ of jobs/employees covered by activity $\quad 70 \%$

moderate -- $40-59 \%$ of jobs/employees covered by activity $50 \%$

some -- $20-39 \%$ of jobs/employees covered by activity $\quad 30 \%$

little -- $1-19 \%$ of jobs/employees covered by activity $\quad 10 \%$ 
Table 4. Regression Coefficients for Production Function Estimates of Effects of EI Scale, PGI Scales, Employment, and Assets on LN(Sales)

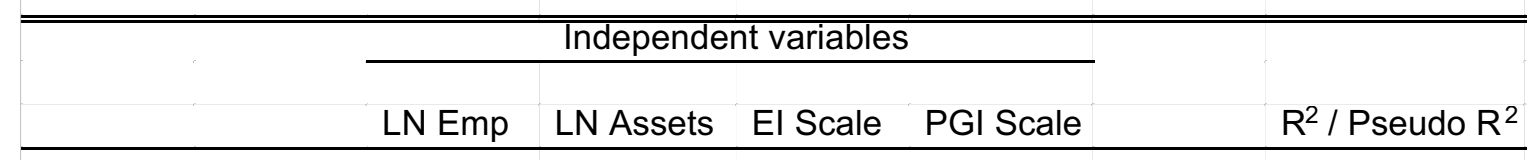

A. Annual Data $(n=2,127$, with year and firm dummies)

\begin{tabular}{|r|r|r|r|r|r|}
\hline OLS & 0.477 & 0.521 & -0.000 & 0.002 & 0.93 \\
\hline & $(0.023)$ & $(0.022)$ & $(0.002)$ & $(0.004)$ & \\
\hline Median & 0.404 & 0.574 & -0.000 & 0.012 & 0.82 \\
\hline & $(0.010)$ & $(0.010)$ & $(0.001)$ & $(0.002)$ & \\
\hline
\end{tabular}

B. 1993 Cross Section $(n=237)$

\begin{tabular}{|r|r|r|r|r|r|}
\hline OLS & 0.445 & 0.560 & -0.005 & 0.028 & 0.92 \\
\hline Median & $(0.054)$ & $(0.050)$ & $(0.006)$ & $(0.012)$ & \\
\hline & 0.411 & 0.558 & -0.003 & 0.008 & 0.81 \\
\hline
\end{tabular}

C. $1983-1993$ Change $(n=237)$

\begin{tabular}{|l|r|r|r|r|r|}
\hline OLS & 0.452 & 0.554 & -0.003 & 0.014 & 0.92 \\
\hline Median & $(0.054)$ & $(0.050)$ & $(0.006)$ & $(0.011)$ & \\
\hline & 0.411 & 0.561 & 0.000 & 0.008 & 0.81 \\
\hline \hline
\end{tabular}

Notes: The 1983-1993 regressions include all years for which we have data. The 1993 regression covers 1993 in cross section; 1983-1993 change includes all companies for which we could get at least two years, with changes calculated as average annual change over the longest period for which data exist. The 1993 and 1983-1993 regressions include seven industry dummy variables, which have no noticeable impact on the results. Standard errors in parentheses.

Source: COMPUSTAT, various years. 
Table 5. Percentage of Workers Who Report Benefitting from Employee Involvement.

Have you personally benefitted from your involvement in the program by getting?

$\begin{array}{ll}\text { An increase in pay? } & 36 \% \\ \text { Getting more influence of job } & 79 \%\end{array}$

As part of this program, do you ever talk about wages and benefits?

Yes, sometimes $26 \%$

Just production issues $\quad 71 \%$

How effective have these programs been in improving productivity or quality?

Very Effective $\quad 32 \%$

Somewhat Effective $\quad 55 \%$

Not too/Not at all $\quad 11 \%$

If your company got rid of the employee involvement program, how would it affect you personally? $^{\mathrm{a}}$

$\begin{array}{lc}\text { Good } & 5 \\ \text { Wouldn't care } & 22 \\ \text { Bad } & 48 \\ \text { Very bad } & 23\end{array}$

If employees, as a group, had more say in how these programs are run at your company, do you think they would be more or less effective?
More
$82 \%$

Less

$10 \%$

Source: $\quad$ Tabulated from WRPS. Princeton Survey Research Associates, Worker Representation and Participation Survey, Detailed Tabulations, October 1994 files.

${ }^{a}$ Item from WRPS, Wave Two, Princeton Survey Research Associates, Worker Representation and Participation Survey, Detailed Tabulations, January 1995 files. 
Table 6. Percentage of Workers Who Assess Workplace by EI status and participation in program.

Firm Has EI Program

No EI Program at Firm

Participates Does Not Participate

\section{Individual's Job}

How much direct involvement do you have in ...

Deciding how to do your job?
A lot
68
52
50
Only a little/none
10
6
17

Setting goals for your work group?
A lot
Only a little/none

Setting work schedules?
A lot
Only a little/none

Deciding what training is needed for people in your work group?
A lot
43
23
23
Only a little/none
19
46
46

Setting safety standards and practices?
A lot
44
31
30
Only a little/none
34
44
42

Deciding how to work with new equipment or software?
A lot
38
26
23
Only a little/none
23
41
42
Do you supervise other employees
48
28
32

or tell other employees what to do?*

Overall, how satisfied are you with the influence you have in company decisions that affect your job or work life?
Very 34
19
19
Not too/not at all
12
24
29

What best describes your feeling about going to work?

Look forward to it

25

30

Source: Tabulated from WRPS. Princeton Survey Research Associates, Worker Representation and Participation Survey, Detailed Tabulations, October 1994 files. A =Items from WRPS, Wave Two, Princeton Survey Research Associates, Worker Representation and Participation Survey, Detailed Tabulations, January 1995 files.

*Based on non-managerial employees only. 
Table 7. The Relation Between Employee Involvement and Attitudes Toward Management and Unionization.

Firm Has EI Program

No EI Program at Firm

Participates Does Not Participate

\section{Attitudes Toward Company/Management}

How much loyalty do you feel toward the company you work for as a whole?
A lot
63
52
49
Only a little/none
8
15
17

In general, how much do you trust your company to keep its promises to you and other employees?
A lot
49
36
30
Only a little/none
12
18
28

How would you rate relations between employees and management?

$\begin{array}{llll}\text { Excellent } & 21 & 14 & 17 \\ \text { Only Fair/Poor } & 25 & 36 & 36\end{array}$

Do you think relations between employees and management are ... than average?

$\begin{array}{lccc}\text { Better } & 50 & 35 & 31 \\ \text { Worse } & 5 & 8 & 13\end{array}$

If you were to rate the performance of employees in your company on a scale similar to school-grades, what grade would you give in ... ${ }^{\mathrm{a}}$

Concern for Employees
A
27
21
$\mathrm{D} / \mathrm{F}$
9
21

Giving Fair Pay Increases/Benefits
A
23
15
$\mathrm{D} / \mathrm{F}$
12
26

Perceptions of Company Labor Relations Practices

How effective is your company's system for resolving the problems individual employees have at work?

$\begin{array}{llll}\text { Very } & 38 & 26 & 22 \\ \text { Not too/Not at all } & 13 & 16 & 29\end{array}$

\section{Attitudes Toward Unions/Workplace Organizations}

(Employees without unions or employee committee that meets with management regularly.) Imagine employees chose their own representatives to meet with management and discuss problems. (Compared to your current system) would this be ...
More effective
60
72
70
Less effective
35
21
23

If an election were held today to decide whether employees like you should be represented by a union, would you vote ...
For the Union
23
27
39
Against the Union
67
61
47

How do you think your fellow employees would vote?

$\begin{array}{llll}\text { For the Union } & 35 & 37 & 45 \\ \text { Against the Union } & 52 & 51 & 39\end{array}$

If it was your decision ... would you prefer an employee organization

where outside arbitration or management make

final decision if disagreement?
Arbitrator 
Source: Tabulated from WRPS. Princeton Survey Research Associates, Worker Representation and Participation Survey, Detailed Tabulations, October 1994 files. ${ }^{a}$ Items from WRPS, Wave Two, Princeton Survey Research Associates, Worker Representation and Participation Survey, Detailed Tabulations, January 1995 files. 
Figure 1 . EID istributions

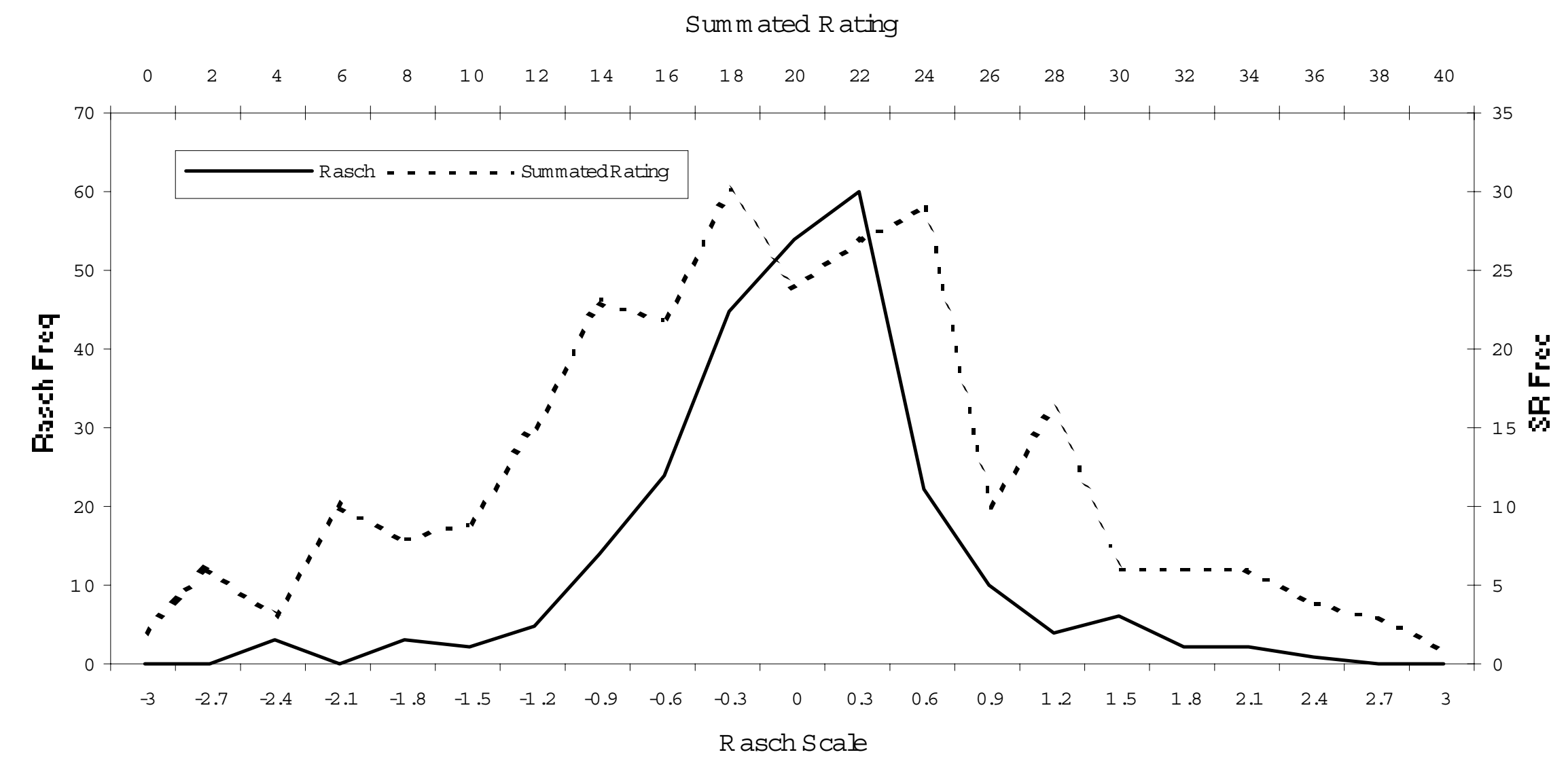




\section{Appendix A}

\section{Percentage of Employment by Company's Primary Industry in the HRP Sample and COMPUSTAT files, 1993}

\begin{tabular}{lcc}
\hline & HRP Sample & COMPUSTAT \\
\hline Agriculture, Mining, and Construction & $4.2 \%$ & $7.1 \%$ \\
Manufacturing & $54.6 \%$ & $45.2 \%$ \\
Transportation & $10.0 \%$ & $10.0 \%$ \\
Wholesale and Retail Trade & $11.2 \%$ & $11.5 \%$ \\
Finance, Insurance, Real Estate & $10.8 \%$ & $12.3 \%$ \\
Services & $9.2 \%$ & $13.9 \%$ \\
\hline
\end{tabular}

2. Means and Standard Deviations of Variables (in parenthesis) in the HRP-COMPUSTAT Matched File, 1983-1993

\begin{tabular}{lcc}
\hline & \multicolumn{2}{c}{ Total Sample $N=260$} \\
\hline Variables & 1983 & 1993 \\
\hline Sales (\$) & $1,674,434,636$ & $2,436,721,796$ \\
& $(5,156,946,938)$ & $(9,297,722,500)$ \\
Employment & 14,978 & 13,960 \\
& $(27,970)$ & $(52,470)$ \\
Sales Per Employee & 127,292 & 188,820 \\
& $(165,158)$ & $(190,012)$ \\
Assets Per Employee & 193,961 & 328,788 \\
& $(370,173)$ & $(948,395)$ \\
\hline
\end{tabular}




\section{Appendix B}

The Percentage of Employees Involved in EI in the U.S. Private Sector, 1994

\begin{tabular}{|c|c|c|c|}
\hline & \multicolumn{2}{|c|}{ Firm Has EI Program } & \multirow[t]{2}{*}{ No EI Program at Firm } \\
\hline & Participates & Does Not Participate & \\
\hline All Workers, firms $15+$ employees & 31 & 21 & 48 \\
\hline \multicolumn{4}{|l|}{ FIRM CHARACTERISTICS } \\
\hline $100+$ & 36 & 28 & 36 \\
\hline $25-99$ & 23 & 9 & 68 \\
\hline Mfg. & 39 & 23 & 38 \\
\hline Retail Trade & 20 & 17 & 63 \\
\hline Union & 35 & 26 & 40 \\
\hline Nonunion & 30 & 19 & 50 \\
\hline \multicolumn{4}{|l|}{ DEMOGRAPHICS } \\
\hline White Collar & 34 & 22 & 44 \\
\hline Blue Collar & 27 & 19 & 54 \\
\hline$<35$ & 27 & 20 & 53 \\
\hline $35-44$ & 35 & 22 & 43 \\
\hline$>55$ & 29 & 19 & 52 \\
\hline Male & 34 & 18 & 48 \\
\hline Female & 28 & 23 & 49 \\
\hline$<$ H.S. & 24 & 20 & 56 \\
\hline College + & 38 & 22 & 40 \\
\hline
\end{tabular}

Source: $\quad$ Tabulated from WRPS. Princteon Survey Research Associates, Worker Representation and Participation Survey, Detailed Tabulations, October 1994 files. 